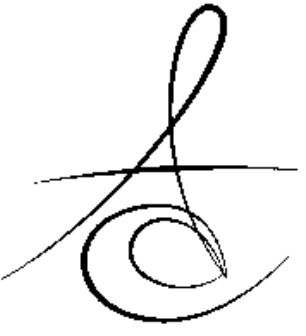

Makale Kodu/Article code: 3342

Makale Gönderilme tarihi: 31.01.2017

Kabul Tarihi: 29.03.2017

\section{EFFECTS OF DIFFERENT CONCENTRATIONS OF PHYTIC ACID ON SMEAR LAYER REMOVAL AND EROSION}

\section{FARKLI KONSANTRASYONLARDA KULLANILAN FİTİK ASİT SOLÜSYONLARININ SMEAR TABAKASININ UZAKLAŞTIRILMASI VE DENTİN EROZYONU ÜZERİNDEKİ ETKİLERİ}

Dr. Dt. Mehmet KALÇAY*

Prof. Dr. Ali Cemal TINAZ*

\section{ABSTRACT}

Aim: The purpose of this study is to evaluate and compare the effects of different concentrations of phytic acid on smear layer removal and erosion.

Materials and Methods: Sixty freshly extracted, single-rooted, mandibular second premolar teeth with relatively similar dimensions and lengths were selected for this study. All of the teeth were instrumented with Protaper Universal files, using the crown-down technique up to size 30, 0.06 taper (F3). Groups are as follows; Group 1 (Control): $5 \mathrm{~mL}$ distilled water (1 min), Group 2: $5 \mathrm{~mL}$ 17\% EDTA (1 min), Group 3: 5 $\mathrm{mL} 1 \%$ phytic acid (1 $\mathrm{min})$, Group 4: $5 \mathrm{~mL} \mathrm{0.5 \%}$ phytic acid (1 $\mathrm{min}$ ). Root canals were irrigated between each file with $2 \mathrm{ml}, 5 \% \mathrm{NaOCl}$. Photomicrographs were taken at x2000 magnification, from the coronal, middle and apical third of each specimen for evaluation.

Results: The $1 \%$ phytic acid solution proved to be more effective than the conventional 17\% EDTA solution even when the concentration was reduced by $50 \%$. Seventeen percent EDTA solution was effective in the removal of the smear layer at the coronal and middle thirds of the root canal. However, the solution was not as effective at the apical third of the root canal. While specimens treated with the $1 \%$ phytic acid caused the highest erosion, the $0.5 \%$ phytic acid and $17 \%$ EDTA followed.

Conclusions: There is very little research to suggest that phytic acid can be used as an alternate root canal chelating agent. Therefore, more research needs to be conducted to be able to evaluate the effects of phytic acid solution on the root canal dentine.

Keywords: Smear layer, phytic acid, erosion, chelating agents
Amaç: Bu çalışmanın amacı tek köklü dişlerde son irrigasyon ajanı olarak farklı konsantrasyonlarda kullanılan fitik asit solüsyonlarının smear tabakasını uzaklaştırıma etkinliğinin, erozyon üzerindeki etkilerinin diğer irrigasyon solüsyonları ile karşılaştırılmasıdır.

Gereç ve Yöntem: Altmış adet, tek köklü insan alt çene ikinci premolar dişler çalışmada kullanılmıştır. Dişler döner alet yardımıyla genişletildi. Ni-Ti Protaper Universal döner eğeleri ile üretici firma talimatlarına göre sırasıyla SX, S1, S2, F1, F2 ve F3 enstrumanlar kullanılarak genişletildi. Her deney grubunda farklı solüsyonlar son irrigasyon ajanı olarak kullanıldı. Gruplar; Grup 1 (Kontrol): $5 \mathrm{~mL}$ distile su (1 dk), Grup 2: $5 \mathrm{~mL}$ 17\% EDTA (1 dk), Grup 3: $5 \mathrm{~mL} 1 \%$ fitik asit ( $1 \mathrm{dk}$ ), Grup 4: $5 \mathrm{~mL} 0.5 \%$ fitik asit (1 dk). Smear tabaka ve erozyon değerlendirmesi, köklerden alınan vertikal kesitlerin, taramalı elektron mikroskobu altında, x2000 büyütmede, köklerin koronal, orta ve apikal üçlüsünden alınan görüntüler kullanılarak yapıldı.

Bulgular:Çalışmanın sonuçlarına göre \%1 fitik asit solüsyonu, solüsyonun konsantrasyonu yarı yarıya azaltılsa bile (\%0,5 fitik asit), konvansiyonel şelasyon ajanı \%17 EDTA'dan smear tabakasını uzaklaştırma kabiliyeti açısından daha etkilidir. \%17 EDTA solüsyonu, koronal ve orta üçlü seviyelerinde etkili bir şekilde smear tabakasını uzaklaştırırken, apikal üçlü seviyesinde aynı etkiyi gösterememiştir. Solüsyonun pH'sının bu kadar asidik olması ve yüksek şelasyon yeteneği olmasına rağmen, dentinde orta derecede erozyona neden olmuştur.

Sonuçlar: Fitik asit solüsyonunun, kök kanal sisteminde meydana getirdiği olumlu ve olumsuz etkilerin daha iyi anlaşılması, kök kanal tedavisinde klinik koşullarda kullanılabilirliğinin değerlendirilmesi için daha fazla in vivo ve in vitro bilimsel çalışmalar yapılması gerekmektedir.

Anahtar Kelimeler: Smear tabakası, fitik asit, erozyon, şelatör ajanlar

\footnotetext{
* Gazi Üniversitesi Diş Hekimliği Fakültesi, Endodonti AD. Ankara.
} 


\section{INTRODUCTION}

Due to the complex anatomy of the root canal systems, it is impossible to achieve a sterile root canal system with only mechanical preparation. ${ }^{1}$ Irrigation, which aids in the elimination of microorganisms, tissue dissolution, cleaning and chelating is a vital step during root canal treatment. ${ }^{2}$ Studies have demonstrated that instrumentation leaves a smear layer covering the dentinal tubule orifices of the root canal dentine. ${ }^{3}$ Despite many arguments to maintain this layer, previous research has proven that the smear layer consists of bacteria and necrotic tissue, and retains the bacteria within the dentinal tubules. ${ }^{4}$ The removal of the smear layer is favoured because it improves the adaptation of the filling materials to the dentinal wall ${ }^{5}$ and allows the irrigating solutions and root canal medicaments to penetrate deeper into the dentine tubules. ${ }^{6}$ Therefore, the search for an ideal irrigation solution with broad anti-microbial properties and effective smear layer removal continues. Most irrigation solutions in use today fail to eliminate the smear layer, especially from the apical third of the root canals. $^{7}$

Sodium hypochlorite $(\mathrm{NaOCl})$ is the most widely used irrigation agent with a broad anti-microbial spectrum and the ability to dissolve organic tissues. ${ }^{2}$ Different concentrations of $\mathrm{NaOCl}$ ranging from $1 \%$ $5.25 \%$ are used. ${ }^{1}$ Despite its superior antimicrobial properties, sodium hypochlorite $(\mathrm{NaOCl})$ fails to eliminate the smear layer covering the root canal walls. ${ }^{8}$

Nygaard-Østby ${ }^{9}$ first introduced chelating agents in endodontics in 1957 to aid in the preparation of narrow and calcified root canals. Chelation is a physiochemical process that induces the uptake of multivalent positive ions by specific chemical substances. ${ }^{10}$ The most common chelating agent is ethylenediamine tetra-acetic acid (EDTA). The disodium salt of EDTA forms a stable complex with calcium ions, and an equilibrium is established when all the calcium ions have been bound. Therefore, no more dissolution takes place. ${ }^{11}$

The effect of chelating agents mainly depends on the time of application, the $\mathrm{pH}$ of the solution and the concentrations used. ${ }^{12}$ It has been reported that the consecutive application of EDTA and sodium hypochlorite $(\mathrm{NaOCl})$ effectively removes the smear layer. ${ }^{13}$ However, it has also been reported that application longer than one minute might lead to detrimental alterations in the root canal dentine. ${ }^{14,15}$ These changes might alter the original proportion of organic and inorganic components, which might lead to a reduction in the microhardness of dentine. Although a reduction in microhardness can facilitate instrumentation, it might also affect the clinical performance of endodontically treated teeth, thus resulting in a weakened tooth structure. ${ }^{12,16,17}$

Phytic acid (IP6, inositol hexakisphosphate) is an organic acid that can be extracted from rice bran for low costs. It is composed of six phosphate groups attached to the carbon atoms of a simple carbohydrate ring. ${ }^{18} \mathrm{~A}$ recent study demonstrated that phytic acid could be used as an alternative chelating agent for the removal of the smear layer due to the effective chelation of multivalent cations, such as calcium, magnesium and iron. ${ }^{19}$

The aim of this study is to evaluate and compare the effects of different concentrations of phytic acid solutions on the removal of the smear layer and the erosion of dentine. It is hypothesized that $1 \%$ and $0.5 \%$ phytic acid solutions removed the smear layer as efficiently or more effectively than $17 \%$ EDTA solution.

\section{MATERIALS AND METHODS}

The Ethical Review Board of the Faculty of Dentistry of Ankara University approved this study. Sample size determination

Calculations were made using G*Power software (Version 3.1.7 for Mac) to determine the power and sample size for this study. For a statistical power of $80 \%$, it has been calculated that 15 teeth would be essential for the experiments in this study.

Teeth selection criteria and root canal

\section{instrumentation}

Sixty freshly extracted, single-rooted, mandibular second premolar teeth with relatively similar dimensions and lengths were selected for this study. The teeth used in this study were extracted for periodontal and prosthodontic purposes. A dental operation microscope (Zeiss, Carl Zeiss Meditech Inc, Jena, Germany) was used at $\times 12$ magnification to account for root caries and fractures. Teeth with multiple or calcified canals were excluded from the study. The specimens chosen for the study were stored in sterile saline solution. 
A round bur (Diatech, Coltene Whaledent, Altstatten, Switzerland) was used for standard coronal access and a \#15 K-file (Dentsply, Maillefer, Ballaigues, Switzerland) was used to navigate the root canal. Working length was established at $1 \mathrm{~mm}$ short of the apical foramen. All of the teeth were instrumented with Protaper Universal files, (Dentsply Maillefer, Ballaigues, Switzerland) using the crowndown technique up to size 30, 0.06 taper (F3). Root canals were irrigated between each file with $2 \mathrm{ml}, 5 \%$ $\mathrm{NaOCl}$ using a $30 \mathrm{G}$ needle.

\section{Experimental design}

The crowns were removed using a diamond disc under constant water irrigation, and the roots were randomly divided into four groups according to the final irrigation regimens $(n=15)$. An open experimental system was used in this study. 20 Apical foramen was enlarged by establishing a patency to a size of 30 (F3) file. The experimental setup permitted unrestricted communication between the apical foramen and the external environment. The experimental groups are as follows:

Group 1 (Control): $5 \mathrm{~mL}$ distilled water for 1 minute and $5 \mathrm{~mL}$ of $5 \% \mathrm{NaOCl}$ (Endosolve $\mathrm{HP}$, Istanbul, Turkey) for 1 minute, respectively $(n=15)$.

Group 2: $5 \mathrm{~mL}$ 17\% EDTA (Werax, Spot Dis Deposu A, İzmir, Turkey) for 1 minute and $5 \mathrm{~mL} 5 \% \mathrm{NaOCl}$ for 1 minute, respectively $(n=15)$.

Group 3: $5 \mathrm{~mL} 1 \%$ phytic acid (Sigma-Aldrich, MO, USA) for 1 minute and $5 \mathrm{~mL} 5 \% \mathrm{NaOCl}$ for 1 minute, respectively $(n=15)$.

Group 4: $5 \mathrm{~mL} 0.5 \%$ phytic acid for 1 minute and $5 \mathrm{ml}$ $5 \% \mathrm{NaOCl}$ for 1 minute, respectively $(n=15)$.

After the final irrigation, the roots in each group were irrigated with $2 \mathrm{~mL}$ of distilled water and the canals were dried with F3 paper points. Two longitudinal grooves were prepared on the buccal and lingual surfaces using a diamond disc under constant water irrigation. Penetration to the root canal was carefully avoided. Each root was split into two longitudinal parts using a chisel. Fifteen root halves were obtained for each group. The specimens were then placed in $30 \%, 40 \%, 50 \%, 60 \%, 70 \%, 80 \%$ and $100 \%$ ethanol solutions, respectively. The specimens were then coated with gold palladium for 200 seconds.

\section{Smear layer and erosion evaluation}

One hundred and eighty photomicrographs were taken at x2000 magnification, from coronal third, middle third and apical third of each specimen using a scanning electron microscope (SEM) (Fei Quanta 400 Feg, Philips, Holland). Researcher calibration was achieved by giving scores to previous photomicrographs from past research. The specimens were then coded according to the final irrigation regimen and were scored blindly by two calibrated researchers, described by Caron et al. ${ }^{21}$ The scores were as follows: Score $1=$ no smear layer, dentinal tubules open, Score 2 = small amount of scattered smear layer, and dentinal tubules open, Score $3=$ thin smear layer and dentinal tubules partially open, Score $4=$ partially covered with thick smear layer and Score 5 = total covering with a thick smear layer. The following score system was used for erosion, as described by Mancini et al. ${ }^{7}$ Score $0=$ no erosion, Score $1=$ moderate erosion and Score $2=$ severe erosion. Consensus was achieved by choosing the higher score as the consensus score in both the evaluation of the smear layer and erosion.

\section{Statistical analysis}

Inter-observer agreement was determined as $0.97,0.97$ and 0.95 for the coronal, middle and apical third of the root canal, respectively, using the Cronbach alpha test. The Kruskal Wallis and MannWhitney $U$ tests were used to compare groups, and Friedman and Willcoxon Signed Ranks were used to make comparisons within group. The level of significance was $p=0.05$.

\section{RESULTS}

Figure 1 shows representative photomicrographs at $\times 2000$ magnification. With the exception of the control group, all of the experimental groups removed the smear layer at coronal and middle thirds of the root canals. However, specimens treated with $1 \%$ phytic acid removed the smear layer significantly better than the groups treated with $17 \%$ EDTA $(p=0.000)$ and $0.5 \%$ phytic acid $(p=0.019)$ at the coronal third. There was no significant difference between the groups at the middle third of the root canal with the exception of the control group. At the apical third, only the $1 \%$ phytic acid group had partially removed the smear layer. There was a thin smear layer and the dentinal tubules were partially 
open in the majority of the photomicrographs. Root canals irrigated with $0.5 \%$ phytic acid had significantly removed the smear layer better than 17\% EDTA $(p=0.012)$ (Table1). Specimens treated with distilled water showed heavily smeared walls at all three thirds of the root canal. Figure 2 presents the smear score distribution for the experimental groups at the coronal, middle and apical third of the root canal.

Figure 3 presents the erosion score distribution for the experimental groups at the coronal, middle and apical third of the root canal. Moderate erosion was observed at the coronal third. However, there was no significant difference between the groups except in the control group. More severe erosion was observed in the specimens at the middle third of the root canal. While specimens treated with $1 \%$ phytic acid caused the highest erosion, $0.5 \%$ phytic acid and $17 \%$ EDTA followed (Figure 4). Differences between the groups were significant $(p<0.05)$. At the apical third of the root canals, specimens treated with $1 \%$ phytic acid caused the highest erosion, followed by $0.5 \%$ phytic acid and $17 \%$ EDTA. No erosion was observed in the control group. (Table 2)
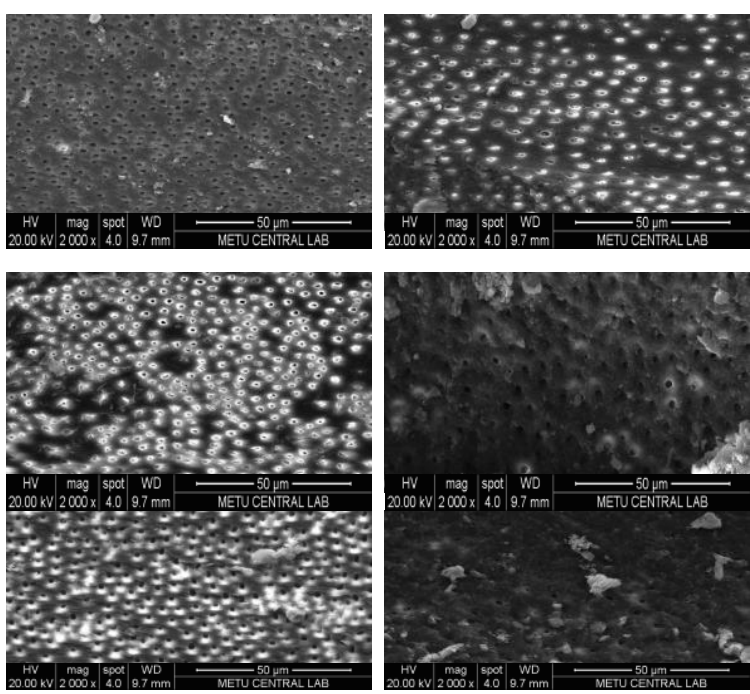

Figure 1. Representative photomicrographs at x2000 magnification for the groups. (A: $1 \%$ phytic acid, middle third, score 1, B: \%1 phytic acid, apical third, score 3, C: $0.5 \%$ phytic acid, middle third, score 2, D: $0.5 \%$ phytic acid, apical third, score 4, E: \%17 EDTA, middle third, score 2, F: \%17 EDTA, apical third, score 5).

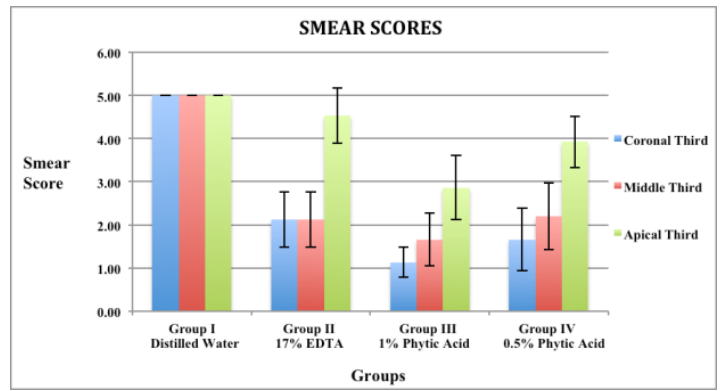

Figure 2. Smear score distribution for the experimental groups at the coronal, middle and apical third of the root canal.

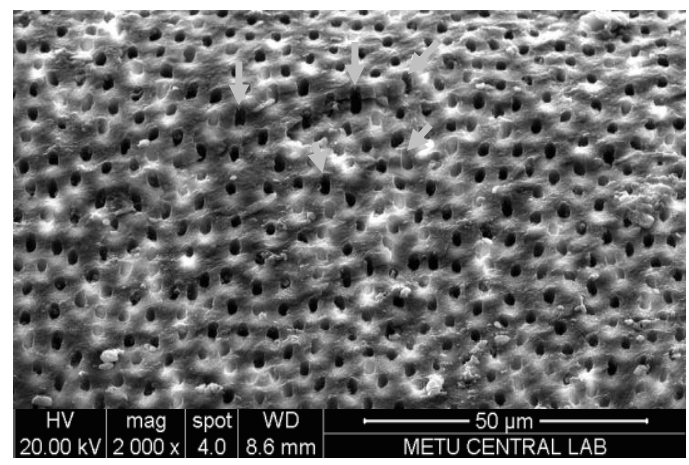

Figure 3. SEM photomicrograph at $\times 2000$ magnification from the middle third of the root canal ( $1 \%$ phytic acid). The white arrows show the merging of the dentine tubules as a result of intertubular erosion.

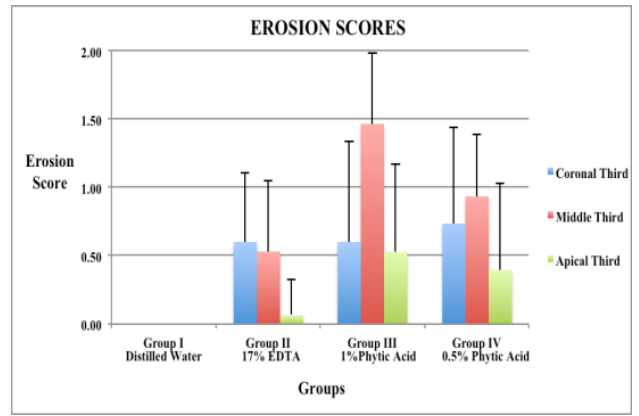

Figure 4. Erosion score distribution for the experimental groups at the coronal, middle and apical third of the root canal.

\section{DISCUSSION}

Mechanical instrumentation of the root canal either by hand files or rotary instruments produced a smear layer that covered the surface of the root canal wall. ${ }^{11}$ There are disagreements over whether to 
Table 1. Mean score, \pm standard deviation and comparison of the smear layer scores between the four experimental groups at the coronal, middle and apical third.

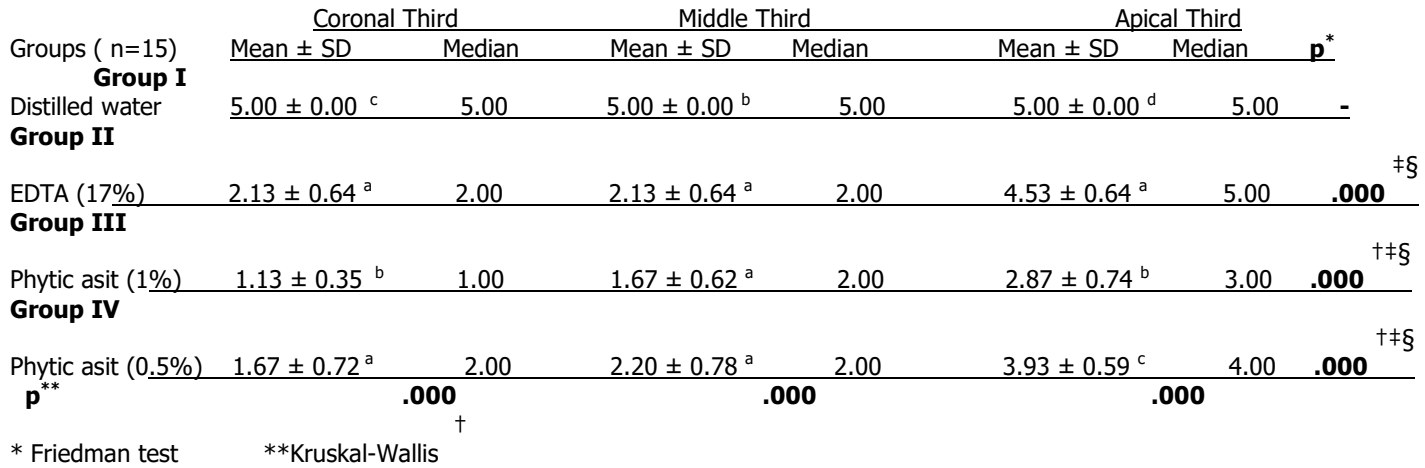

remove or maintain the smear layer, but a recent review and a meta-analysis of microleakage studies reported that the removal of the smear layer ultimately enhances the fluid-tight seal of the root canal system. ${ }^{22}$ However, most irrigation solutions used to remove the smear layer fail, especially at the apical third of the root canal. ${ }^{7}$

The purpose of this study was to evaluate and compare the effects of different concentrations of phytic acid solution on the removal of the smear layer and erosion on dentine. Both concentrations of phytic acid used were more effective at removing the smear layer compared with 17\% EDTA and the control group.

Regarding the removal of the smear layer from the root canal walls, $\mathrm{NaOCl}$ is proven to be ineffective as photomicrographs revealed a root canal surface with dentinal tubules heavily smeared with smear plugs and debris. These findings are in accordance with previous research by Ciucci et al. and O'Connell et al. ${ }^{13,23}$

There are many controversies regarding the application time of EDTA solutions in the literature. Cergneux et al. ${ }^{24}$ reported that a four minute application time for $15 \%$ EDTA has been effective for the removal of the smear layer, while others reported a one-minute application time was adequate for the of EDTA changes while demineralizing the dentine. As removal of the smear layer with 10\% EDTA. ${ }^{14}$

The $\mathrm{pH}$ increases, the rate of demineralization decreases, resulting in a decline in dentinal demineralization. Thus, it is recommended to use a short application time with EDTA. ${ }^{25}$ In this study, $5 \mathrm{ml}$ of each final irrigation solution was used for one minute. Following irrigation with the final irrigation agents, $5 \mathrm{ml}$ of $\mathrm{NaOCl}$ and $2 \mathrm{ml}$ of distilled water were used for one minute, respectively. The one-minute application of phytic acid solution was adapted from the study by Nassar et al. ${ }^{19}$

The consecutive application of EDTA and $\mathrm{NaOCl}$ has been proven to effectively remove the smear layer at the coronal and middle third of the root canal. However, the consecutive use of these solutions has been ineffective at the apical third of the root canal. ${ }^{23}$ The main reason for this may be that the irrigation solutions cannot penetrate deep into the apical third of the root canal. ${ }^{26}$ The results of this study are in accordance with O'Connell et al. ${ }^{23}$ EDTA removed the smear layer effectively at the coronal and middle thirds of the root canal; however, it failed to remove the smear layer at the apical third.

Nassar et al. ${ }^{19}$ investigated the efficacy of $1 \%$ phytic acid in removing the smear layer. Smear layer removal efficacy was determined by using $1 \%$ of the solution with two different application times - 1 minute or 30 seconds - and it was observed that $1 \%$ phytic acid removed the smear layer more effectively from the coronal dentine surfaces compared with $17 \%$ EDTA. Additionally, better results were observed with $1 \%$ phytic acid at the middle and apical thirds of the root canal in comparison with 17\% EDTA. However, it has been highlighted that a cleaner root canal surface was observed at the middle third when compared with the apical third of the root canal. Similar findings were also obtained in this study. The findings of this study are in accordance with Nassar et al. ${ }^{19}$ In comparison with $17 \%$ EDTA, both $1 \%$ and $0.5 \%$ phytic acid solutions were found to be more effective in removing the smear layer. The dentinal tubule orifices were 
wider and the root canal walls were cleaner than the other experimental groups. Furthermore, the $0.5 \%$ phytic acid solution was not as effective as the $1 \%$ phytic acid solution. While $0.5 \%$ of phytic acid solution effectively removed the smear layer at the coronal and middle third of the root canal, it was ineffective at the apical third. When compared with $17 \%$ EDTA, the $0.5 \%$ phytic acid solution removed the smear layer significantly better; however, it was less efficient than the $1 \%$ phytic acid.

Past literature investigated the effects of $\mathrm{NaOCl}$ and EDTA on intertubular and peritubular dentine. Niu et al. ${ }^{15}$ reported that separate use of EDTA and $\mathrm{NaOCl}$ solutions has no erosive effect on the intertubular and peritubular dentine. However, researchers highlighted that the consecutive use of these solutions would result in moderate to severe dentinal erosion. Similar findings were observed in the present study. No erosion was observed at the intertubular and peritubular dentine when $\mathrm{NaOCl}$ was used alone. Additionally, when $17 \%$ EDTA and $5 \% \mathrm{NaOCl}$ were used consecutively, the degree of erosion was low. Past literature indicates than when EDTA is used for more than one-minute in the root canal, more erosion is observed. ${ }^{14,26,27}$ The fact that the irrigation solutions were used for one minute in our study, may explain why a very low erosion was observed with the consecutive use of $17 \%$ EDTA and $5 \% \mathrm{NaOCl}$.

There have been no previous investigations into the erosive effects of phytic acid solution. According to the results of this study, at the coronal third, the $1 \%$ phytic acid solution caused a relatively similar degree of erosion in all of the other experimental groups, except the control group. However, at the middle and apical thirds of the root canal, the $1 \%$ phytic acid solution caused significant erosion compared to the other experimental groups. The erosion was highest at the middle third of the root canal. This may be attributed to the high acidity of the solution resulting in the elevation of calcium chelation, leading to a greater destruction of the peritubular dentine. The $0.5 \%$ phytic acid caused higher erosion compared with the $17 \%$ EDTA, but the degree of erosion was less than the $1 \%$ phytic acid.

Nassar et al. ${ }^{19}$ investigated the effect of $1 \%$ phytic acid solution on osteoblastic cells since these cells are of vital importance for periapical healing. It is crucial to assess the effects of different irrigation solutions inside the root canal on the viability and ALP activity of osteoblastic cells. According to the results of this study, the presence of $1 \%$ phytic acid in the culture medium did not affect the morphology, viability or ALP activity of cells.

Tay et al. ${ }^{20}$ compared open and closed experimenttal designs to determine the differences in the smear layer and debris removal. While there were no differrences between the two experimental designs regarding the smear layer removal at each level of the root canal, it was reported that the closed system resulted in more debris at the apical third of the root canal. However, since the determination of the amount of debris was not the main purpose of this study, an open experimental design was selected because there were no differences between the two experimental designs regarding the removal of the smear layer.

Within the limitations of this study, $1 \%$ phytic acid with an application time of one minute was the most effective smear layer removal agent at each level of the root canal followed by $0.5 \%$ phytic acid and $17 \%$ EDTA. Additionally, $1 \%$ phytic acid caused the greatest erosion followed by $0.5 \%$ phytic acid and $17 \%$ EDTA. There is limited research suggesting the use of phytic acid as an alternating root canal chelating agent. More research needs to be conducted to be able to evaluate the effects of phytic acid solution on the root canal dentine.

Mehmet Kalçay: 0000-0002-2162-6972

Ali Cemal Tınaz: 0000-0001-7285-234X

\section{REFERENCES}

1. Torabinejad $M$, Handysides $R$, Khademi AA, Bakland LK. Clinical implications of the smear layer in endodontics: A review, Oral Surg, Oral Med, Oral Pathol, Oral Radiol Endod 2002;94:658-66.

2. Ulusoy OIA, Gorgul G. Effects of different irrigation solutions on root dentine microhardness, smear layer removal and erosion, Aust Endod J 2011; 39: 66-72.

3. Orstavik D, Haapasalo M. Disinfection by endodontic irrigants and dressings of experimentally infected dentinal tubules, Dent Traumatol 1990;6:142-9.

4. Yamada RS, Armas A, Goldman M, Lin PS. A scanning electron microscopic comparison of a high volume final flush with several irrigating solutions: Part 3, J Endod 1983;9:137-42. 
5. Karagoz-Kucukay I, Bayirli G. An apical leakage study in the presence and absence of the smear layer, Int Endod J. 1994;27:87-93.

6. Economides N, Liolios E, Kolokuris I, Beltes P. Long-term evaluation of the influence of smear layer removal on the sealing ability of different sealers, J Endod 1999;25:123-5.

7. Mancini M, Armellin E, Casaglia A, Cerroni L, Cianconi L. A Comparative Study of Smear Layer Removal and Erosion in Apical Intraradicular Dentine with Three Irrigating Solutions: A Scanning Electron Microscopy Evaluation, J Endod 2009;35:900-3.

8. Zehnder $M$ Root Canal Irrigants, J Endod 2006;32:389-98.

9. Nygaard-Ostby B. Chelation in root canal therapy: ethylenediamine tetraacetic acid for cleansing and widening of root canals, Odontol Tidskr. 1957;65:3-11.

10. Rotstein I, Dankner E, Goldman A, Heling I, Stabholz A, Zalkind M. Histochemical analysis of dental hard tissues following bleaching, J Endod 1996;22:23-6.

11. Hülsmann $M$, Heckendorff $M$, Lennon Á. Chelating agents in root canal treatment: mode of action and indications for their use, Int Endod J 2003;36: 810-30.

12. Pérez-Heredia M, Ferrer-Luque CM, GonzálezRodríguez MP, Martín-Peinado FJ, González-López S. Decalcifying effect of $15 \%$ EDTA, $15 \%$ citric acid, $5 \%$ phosphoric acid and $2.5 \%$ sodium hypochlorite on root canal dentine, Int Endod J. 2008;41:418-23.

13. Ciucchi B, Khettabi M, Holz J. The effectiveness of different endodontic irrigation procedures on the removal of the smear layer: a scanning electron microscopic study, Int Endod J. 1989;22:21-8.

14. Calt S, Serper A. Time-Dependent Effects of EDTA on Dentin Structures, J Endod 2002;28:17-9.

15. Niu W, Yoshioka T, Kobayashi C, Suda H. A scanning electron microscopic study of dentinal erosion by final irrigation with EDTA and $\mathrm{NaOCl}$ solutions, Int Endod J. 2002;35:934-9.

16. Cruz-Filho AMD, Paula EAD, Pécora JD, Sousa-Neto MDD. Effect of different EGTA concentrations on dentin microhardness, Braz Dent J 2002;13:188-90

17. Cruz-Filho AM, Sousa-Neto MD, Savioli RN, Silva RG, Vansan LP, Pécora JD. Effect of Chelating Solutions on the Microhardness of Root Canal Lumen Dentin, J Endod 2011;37:358-62.
18. Shamsuddin AM. Anti-cancer function of phytic acid, Int J Food Sci and Technol. 2002;37:769-82.

19. Nassar M, Hiraishi N, Tamura Y, Otsuki M, Aoki K, Tagami J. Phytic Acid: An Alternative Root Canal Chelating Agent, J Endod 2015;41:242-7.

20. Tay FR, Lisha G, Schoeffel GJ et al. The effect of vapor lock on root canal debridement using a sidevented needle for positive- pressure irrigant delivery, J Endod 2010;36:745-50.

21. Caron G, Nham K, Bronnec F, Machtou P. Effectiveness of Different Final Irrigant Activation Protocols on Smear Layer Removal in Curved Canals, J Endod 2010;36:1361-6.

22. Shahravan A, Haghdoost A, Adl A, Rahimi H, Shadifar F. Effect of Smear Layer on Sealing Ability of Canal Obturation: A Systematic Review and Metaanalysis, J Endod 2007;33:96-105.

23. O'Connell, M., Morgan, L., Beeler, W., and Baumgartner, J. A Comparative Study of Smear Layer Removal Using Different Salts of EDTA, J Endod 2000;26,739-43.

24. Cergneux, M., Ciucchi, B., Dietschi, J. M., Holz, J. The influence of the smear layer on the sealing ability of canal obturation, Int Endod J 1987; 20: 228-32.

25. Garberoglio, R. and Becce, C. Smear layer removal by root canal irrigants, Oral Surg, Oral Med, Oral Pathol. 1994; 78: 359-67.

26. Torabinejad M, Khademi A, Babagoli J, Cho Y, Johnson W, Bozhilov K, et al. A New Solution for the Removal of the Smear Layer, J Endod 2003; 29: 170-5.

27. Mutluay AT, Mutluay M. Sodium hypochlorite in endodontics, J Dent Fac Ataturk Uni 2015;25:25865.

\section{Yazışma Adresi}

Dt. Mehmet KALÇAY

Gazi Üniversitesi, Diş Hekimliği Fakültesi, Endodonti Anabilim Dalı, B blok 5.kat, 8.Cadde 1.Sokak, Emek, Ankara, TURKEY

TIf : 00905353805335

e- posta : dtmehmetkalcay@gmail.com 